\title{
One-Pot Surfactant-Free Synthesis of Transition Metal/ZnO Nanocomposites for Catalytic Hydrogenation of $\mathrm{CO}_{2}$ to Methanol
}

\author{
LIU Yanfang, HU Bing, YIN Yazhi, LIU Guoliang *, HONG Xinlin * \\ College of Chemistry and Molecular Sciences, Wuhan University, Wuhan 430072, P. R. China.
}

\begin{abstract}
Catalytic hydrogenation of $\mathrm{CO}_{2}$ to methanol is an important chemical process owing to its contribution in alleviating the impacts of the greenhouse effect and in realizing the requirement for renewable energy sources. Owing to their excellent synergic functionalities and unique optoelectronic as well as catalytic properties, transition metal/ZnO $(\mathrm{M} / \mathrm{ZnO})$ nanocomposites have been widely used
\end{abstract}

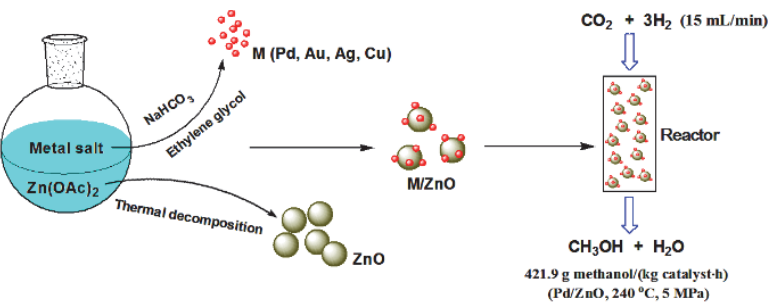
as catalysts for this reaction in recent years. Development of size-controlled synthesis of metal/oxide complexes is highly desirable. Further, because it is extremely difficult to achieve the strong-metal-support-interaction (SMSI) effect when the $\mathrm{M} / \mathrm{ZnO}$ nanocomposites are prepared via physical methods, the use of chemical methods is more favorable for the fabrication of multi-component catalysts. However, because of the requirement for an extra $\mathrm{H}_{2}$ reduction step to obtain the active metallic phase $(\mathrm{M})$ and surfactants to control the size of nanoparticles, most $\mathrm{M} / \mathrm{ZnO}$ nanocomposites undergo two- or multi-step synthesis, which is disadvantageous for the stable catalytic performance of the $\mathrm{M} / \mathrm{ZnO}$ nanocomposites. In this work, we demonstrate facile one-pot synthesis of $\mathrm{M} / \mathrm{ZnO}(\mathrm{M}$ $=\mathrm{Pd}, \mathrm{Au}, \mathrm{Ag}$, and $\mathrm{Cu}$ ) nanocomposites in refluxed ethylene glycol as a solvent, without using any surfactants. During the synthesis process, $\mathrm{Pd}$ and $\mathrm{ZnO}$ species can stabilize each other from further aggregation by reducing their individual surface energies, thereby achieving size control of particles. Besides, $\mathrm{NaHCO}_{3}$ serves as a size-control tool for $\mathrm{Pd}$ nanoparticles by adjusting the alkaline conditions. Ethylene glycol serves as a mild reducing agent and solvent owing to its capacity to reduce $\mathrm{Pd}$ ions to generate Pd crystals. The nucleation and growth of Pd particles are achieved by thermal reduction, while the $\mathrm{ZnO}$ nanocrystals are formed by thermal decomposition of $\mathrm{Zn}(\mathrm{OAc})_{2}$. X-ray diffraction patterns of the $\mathrm{M} / \mathrm{ZnO}$ and $\mathrm{ZnO}$ were analyzed to study the phase of the nanocomposites, and the results show that no impurity phase was detected. Transmission electron microscopy (TEM) was used to study the morphology and structural properties. In addition, X-ray photoelectron spectroscopy analysis was performed to further confirm the formation of $\mathrm{M} / \mathrm{ZnO}$ hybrid materials, and the results confirm SMSI between $\mathrm{Pd}$ and $\mathrm{ZnO}$. Inductively coupled plasma mass spectrometry was used to check the actual elemental compositions, and the results show that the detected atomic ratios of Pd/Zn were consistent with the values in the theoretical recipe. To investigate the effects of the $\mathrm{Pd} / \mathrm{Zn}$ molar ratios and the added amount of $\mathrm{NaHCO}_{3}$ on $\mathrm{Pd}$ size, the average sizes of $\mathrm{Pd}$ particles were calculated, and the results were confirmed by TEM observation. The $\mathrm{Cu} / \mathrm{ZnO} / \mathrm{Al}_{2} \mathrm{O}_{3}$ composite is a widely known catalyst for hydrogenation of $\mathrm{CO}_{2}$ to methanol, and other $\mathrm{M} / \mathrm{ZnO}$ composites are also catalytic for this reaction. Therefore, different $\mathrm{M} / \mathrm{ZnO}$ hybrids were further studied as catalysts for hydrogenation of $\mathrm{CO}_{2}$ to methanol, among which $\mathrm{Pd} / \mathrm{ZnO}(1: 9)$ demonstrated the best performance $\left(30 \% \mathrm{CO}_{2} \mathrm{Conversion}\right.$, $69 \%$ methanol selectivity, and $421.9 \mathrm{gmethanol} \cdot(\mathrm{kg} \text { catalyst } \cdot \mathrm{h})^{-1}$ at $240^{\circ} \mathrm{C}$ and $5 \mathrm{MPa}$. The outstanding catalytic performance may be explained by the following two factors: first, $\mathrm{Pd}$ is a good catalyst for the dissociation of $\mathrm{H}_{2}$ to give active $\mathrm{H}$ atoms, and second, SMSI between $\mathrm{Pd}$ and $\mathrm{ZnO}$ favors the formation of surface oxygen vacancies on $\mathrm{ZnO}$. Moreover, most M/ZnO composites exhibit excellent performance in methanol selectivity, especially the Au/ZnO catalyst, which has the highest methanol selectivity (82\%) despite having the lowest $\mathrm{CO}_{2}$ conversion. Hopefully, this work would provide a simple route for synthesis of $\mathrm{M} / \mathrm{ZnO}$ nanocomposites with clean surfaces for catalysis.

Received: December 29, 2017; Revised: February 2, 2018; Accepted: February 6, 2018; Published online: February 26, 2018.

*Corresponding authors. Emails: liugl@whu.edu.cn (L.G.); hongxl@whu.edu.cn (H.X.).

This work was financially supported by the National Natural Science Foundation of China (21373153).

国家自然科学基金面上项目(21373153)资助

Editorial office of Acta Physico-Chimica Sinica 
Key Words: Metal/ZnO; Hydrogenation; $\mathrm{CO}_{2}$; Methanol; Nanocomposites

\title{
无表面活性剂条件下一锅法制备金属/氧化锌复合材料用于催化二氧 化碳加氢制甲醇反应
}

\author{
刘艳芳, 胡兵, 尹雅芝, 刘国亮 ${ }^{*}$, 洪昕林 ${ }^{*}$ \\ 武汉大学化学与分子科学学院, 武汉 430072
}

\begin{abstract}
摘要: 由于温室效应的危害和人类对可再生能源的需求, 二氧化碳加氢还原制甲醇成为非常重要的一个化学反应。最近 几年的研究中, 过渡金属/氧化锌纳米复合材料作为催化剂被广泛应用于该反应, 这是因为过渡金属/氧化锌纳米复合材 料具有优秀的协同功能以及独特的光电子和催化性能。因此, 发展该复合材料的尺寸可控制备方法显得很有价值。虽然 使用物理方法可以大批量制备催化材料, 但却难以实现金属和载体间的强相互作用力。因此, 研究者们更多地倾向于使 用化学方法来制备多组分催化剂材料。然而, 为了获取活性金属相, 该催化剂通常需要氢气还原步骤; 同时, 还需要表 面活性剂来控制纳米粒子的尺寸, 这就使得大多数复合纳米材料的合成需要很多步骤, 从而导致金属/氧化锌纳米复合材 料催化性能的不稳定性。因此, 我们发明了一种在回流乙二醇中一锅法合成金属(钯, 金, 银, 铜)/氧化锌纳米复合材料 的制备方法, 该制备方法不需要任何表面活性剂。在该方法的制备过程中, 钯和氧化锌可以通过减少各自的表面能从 而在之后的聚集中互相稳定彼此来实现粒子的尺寸控制。此外, 碳酸氢钠可以通过调整碱性度来控制钯纳米粒子的尺寸。 而乙二醇作为一种温和的还原剂可以将钯离子还原成钯纳米粒子, 同时还可以作为该制备过程的溶剂。在制备过程中, 钯粒子通过热还原而成核和聚集, 氧化锌纳米粒子则通过醋酸锌的热分解而形成。本文中, 我们通过X射线衍射来分析 制备的复合纳米材料的相态, 结果显示, 没有杂相。我们使用透射电镜来研究材料的形貌和结构特征。此外, X射线光 电子能谱分析被用来确认金属氧化锌复合材料的成分组成, 结果显示钯和氧化锌之间有金属和载体间的强相互作用力。 为了确定复合材料的真实元素组成, 我们对材料进行了电感棅合等离子体质谱分析, 并且发现理论值和实验值相吻合。 为了研究钯锌投料比和碳酸氢钠对钯粒子尺寸的影响, 我们通过X射线衍射结果计算出不同钯锌投料比和碳酸氢钠反应 量下钯粒子的尺寸, 并进行比较分析, 之后利用透射电镜图进行进一步直观验证。众所周知, $\mathrm{Cu} / \mathrm{ZnO} / \mathrm{Al}_{2} \mathrm{O}_{3}$ 纳米复合材 料是二氧化碳加氢制甲醇的优良催化剂, 本文中研究的其他金属/氧化锌复合材料也可以很好地催化该反应。所以, 为了 进一步研究所制备的不同金属/氧化锌复合材料, 我们将其作为催化剂, 研究了它们对二氧化碳加氢制甲醇的催化作用; 结果显示, 当钯锌投料比为 $1: 9$, 反应条件为 $240{ }^{\circ} \mathrm{C}, 5 \mathrm{MPa}$ 时, 其催化效果最好, 二氧化碳转化率为 $30 \%$, 甲醇选择 性为 $69 \%$ 。其出色的催化表现可能是以下两个因素, 其一是因为钯是氢气解离为活泼氢原子的良好催化剂; 其二是因为 钯和氧化锌之间的强的金属和载体间相互作用力可以使得氧化锌表面形成表面氧空穴。此外, 我们发现大部分金属/氧化 锌复合物都表现出很高的甲醇选择性, 尤其是金/氧化锌催化剂, 它的甲醇选择性达到了 $82 \%$, 只是二氧化碳转化率较 低。最后, 希望本文可以提供一种制备金属/氧化锌的简便易行的方法, 且该方法可以为金属/氧化锌用于催化时提供干 净的催化表面。
\end{abstract}

关键词：金属/氧化锌；加氢；二氧化碳；甲醇；纳米复合材料 中图分类号: 0643

\section{Introduction}

Nanocomposites, especially functional metal oxide supported transition metal, have attracted intensive research attention in recent years ${ }^{1-5}$. The hybrid systems that consist of two or more components usually exhibit special synergic functionalities and novel optoelectronic, magnetic and catalytic properties over their individual counterparts, making them good candidates in a wide range of application areas, such as biology, solar cells, catalysis and optoelectronic devices ${ }^{6-9}$. Transition metals, especially noble metals, are known to have superior electronic and catalytic properties, which can be further promoted by metal oxide supports in catalysis due to the so-called strong-metal- support-interaction (SMSI) effect ${ }^{10}$. More importantly, through controlling particle size and loading content of metals, their chemical properties can be finely tuned and optimized.

Among transition metal/metal oxide nanocomposites, metal/ZnO $(\mathrm{M} / \mathrm{ZnO})$ system has been widely used as catalysts for several important chemical processes, such as catalytic conversion of syngas to low-carbon alcohols $(\mathrm{Cu} / \mathrm{ZnO})^{11}$, hydrogenation of $\mathrm{CO}_{2}(\mathrm{Cu} \text { or } \mathrm{Pd} / \mathrm{ZnO})^{12}$, $\mathrm{CO}$ oxidation $(\mathrm{Au} / \mathrm{ZnO})^{13}$ and ethanol stream reforming $(\mathrm{Co} \text { or } \mathrm{Ni} / \mathrm{ZnO})^{14}$. In general, $\mathrm{M} / \mathrm{ZnO}$ nanocomposites can be prepared following two strategies, one being physical routes such as ball-milling ${ }^{15}$ (topdown), the other being chemical synthesis methods (bottom-up). 
The former allows the mass production of powder samples, but it is very difficult to achieve SMSI, which has been confirmed to be an important factor in heterogeneous catalysis ${ }^{10}$. Chemical methods could be a better solution to fabricate multi-component catalysts. For example, conventional co-precipitation and wetimpregnation are widely employed for preparation of supported metal catalysts. But they normally require an extra $\mathrm{H}_{2}$ reduction step to obtain active metallic phase (M) from oxide precursor $\left(\mathrm{MO}_{x}\right)$. As the synthesis of individual metal nanoparticles (NPs), especially noble metal NPs, is quite different from that of oxides, especially metal/ZnO, most of metal/oxide nanocomposites involve two or multi-steps synthesis. Therefore, it is of great significance to develop a one-step synthesis procedure.

Since a "hot injection" method was reported by Murray et al. in 1993 16, many other strategies, such as thermal decomposition 17, photodeposition ${ }^{18}$, in situ redox reactions ${ }^{19,20}$ and thermal reduction ${ }^{21-23}$, have been also developed for size-control synthesis of metal or oxide NPs. However, most of the reported methods involve expensive or toxic reagents. Moreover, they normally require the use of surfactants, which, albeit effective in controlling the size of nanoparticles, turns out to be a headache for catalytic applications as the surfactants would block the catalytic surface and thus lower the activity ${ }^{24}$. Therefore, it is quite desirable to develop a simple and versatile route for size-control synthesis of metal/oxide nanocomposites without using any surfactants.

\section{Experimental section}

Here we present a simple one-pot surfactant-free method to synthesize $\mathrm{Pd} / \mathrm{ZnO}$ nanocomposites in refluxed ethylene glycol by combining strategies of thermal decomposition and thermal reduction. Typically, a certain amount of $\mathrm{Na}_{2} \mathrm{PdCl}_{4}, 0.1 \mathrm{~g}$ of $\mathrm{NaHCO}_{3}$ and $5 \mathrm{mmol}$ of $\mathrm{Zn}(\mathrm{OAc})_{2}$ were mixed with $45 \mathrm{~mL}$ of ethylene glycol, followed by a reflux treatment for $30 \mathrm{~min}$ (see detailed procedure in ESI). The particle size and loading content of Pd can be easily tailored by changing the dosage of $\mathrm{NaHCO}_{3}$ and $\mathrm{Na}_{2} \mathrm{PdCl}_{4}$ in the recipe. This new process also proved versatile and can be applied to the fabrication of $\mathrm{Au} / \mathrm{ZnO}$, $\mathrm{Ag} / \mathrm{ZnO}$, and $\mathrm{Cu} / \mathrm{ZnO}$. In addition, we have shown that $\mathrm{M} / \mathrm{ZnO}$ nanocomposites mixed with $\mathrm{Al}_{2} \mathrm{O}_{3}$ can be used as catalysts for $\mathrm{CO}_{2}$ hydrogenation to methanol. After screening, the $\mathrm{Pd} / \mathrm{ZnO}$ catalyst with a $\mathrm{Pd} / \mathrm{Zn}$ ratio of $1: 9$ showed the highest methanol yield.

\section{Results and discussion}

As we know, ethylene glycol, serving as a mild reducing agent and solvent, has been widely used in the synthesis of noble metal NPs ${ }^{25}$. As illustrated in Fig. 1, alcohol hydroxyl groups are capable to reduce Pd ions to generate Pd crystals in refluxing conditions. The "thermal reduction" allows the nucleation and growth of Pd particles without using extra reducing agents. To control the size of Pd NPs, $\mathrm{NaHCO}_{3}$, which acts as a size-control agent, is employed in the system by changing the alkaline conditions. Meanwhile, such high temperature would favor a thermal decomposition of $\mathrm{Zn}(\mathrm{OAc})_{2}$ to form $\mathrm{ZnO}$ nanocrystals ${ }^{26}$. When combining the two routes together, one may expect to obtain hybrid $\mathrm{Pd} / \mathrm{ZnO}$ in one pot. In our surfactant-free system, the new-born species (Pd and $\mathrm{ZnO}$ nanoclusters) would stabilize each other from further aggregation by reducing their individual surface energy in the growth process. Importantly, this approach can be extended to fabricate $(\mathrm{Au}, \mathrm{Cu}$, and $\mathrm{Ag}) / \mathrm{ZnO}$ hybrid nanomaterials by simply changing the metal precursor, verifying the effectiveness and feasibility of this novel approach.

Fig. 2a shows the X-ray diffraction (XRD) pattern of the $\mathrm{Pd} / \mathrm{ZnO}$ sample with a $\mathrm{Pd} / \mathrm{Zn}$ ratio of $1: 6$. Clearly, the signals at $31.8^{\circ}, 34.4^{\circ}$ and $36.3^{\circ}$ can be assigned to (100), (002) and (101) diffraction peaks of wurtzite-ZnO crystals (JCPDS\#211486), suggesting the existence of $\mathrm{ZnO}$. Meanwhile, the peaks at $40.2^{\circ}, 46.6^{\circ}$ and $68.1^{\circ}$ correspond to the (111), (200) and (220) planes of a face centered cubic $(f c c)$ lattice of metallic Pd (JCPDS\#65-6174). No impurity phase was detected by XRD analysis, indicating that the obtained materials were solely comprised of crystallized $\mathrm{Pd}$ and $\mathrm{ZnO}$ lattices. Fig. $2 \mathrm{~b}$ shows a transmission electron microscopy (TEM) image of the $\mathrm{Pd} / \mathrm{ZnO}$ sample. It reveals pseudo sphere-like $\mathrm{ZnO}$ crystals, decorated with small-sized Pd particles, as distinguished from different contrasts. The average size of $\mathrm{ZnO} N P s$ is around $30 \mathrm{~nm}$, while that of Pd is estimated to be about $8 \mathrm{~nm}$. The high-resolution TEM image in Fig. 2c shows a d-spacing value of $0.23 \mathrm{~nm}$, which can be assigned to the characteristic (111) lattice plane of metallic $\mathrm{Pd}^{27}$.

For comparison, pure $\mathrm{ZnO}$ sample was synthesized under the same conditions without adding Pd precursor. The TEM image (Fig. 2d) shows some big spherical aggregates that consist of irregular $\mathrm{ZnO}$ NPs. The size of these aggregates ranges from 30 $\mathrm{nm}$ to $100 \mathrm{~nm}$. It seems that Pd plays an important role in preventing aggregation of $\mathrm{ZnO}$ nanocrystals. This could be explained by the decrease of the surface energy of ZnO NPs after the decoration of new-born Pd nanoclusters on the surface of $\mathrm{ZnO}$.

To further confirm the formation of $\mathrm{Pd} / \mathrm{ZnO}$ hybrid material, XPS analysis was performed. Fig. 3a displays a wide-range XPS spectrum of the $\mathrm{Pd} / \mathrm{ZnO}$ sample, confirming the coexistence of

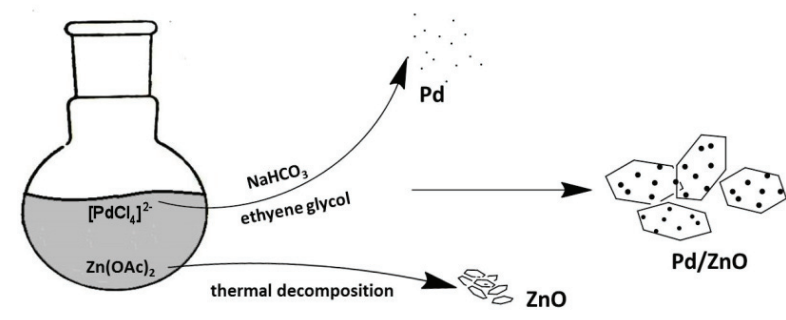

Fig. 1 Schematic illustration of hybrid $\mathrm{Pd} / \mathrm{ZnO}$ nanoparticle fabrication.

This approach can also be extended to fabricate $(\mathrm{Au}$, $\mathrm{Ag}$, and $\mathrm{Cu} / \mathrm{ZnO}$ nanocomposites by changing the metal precursor. 

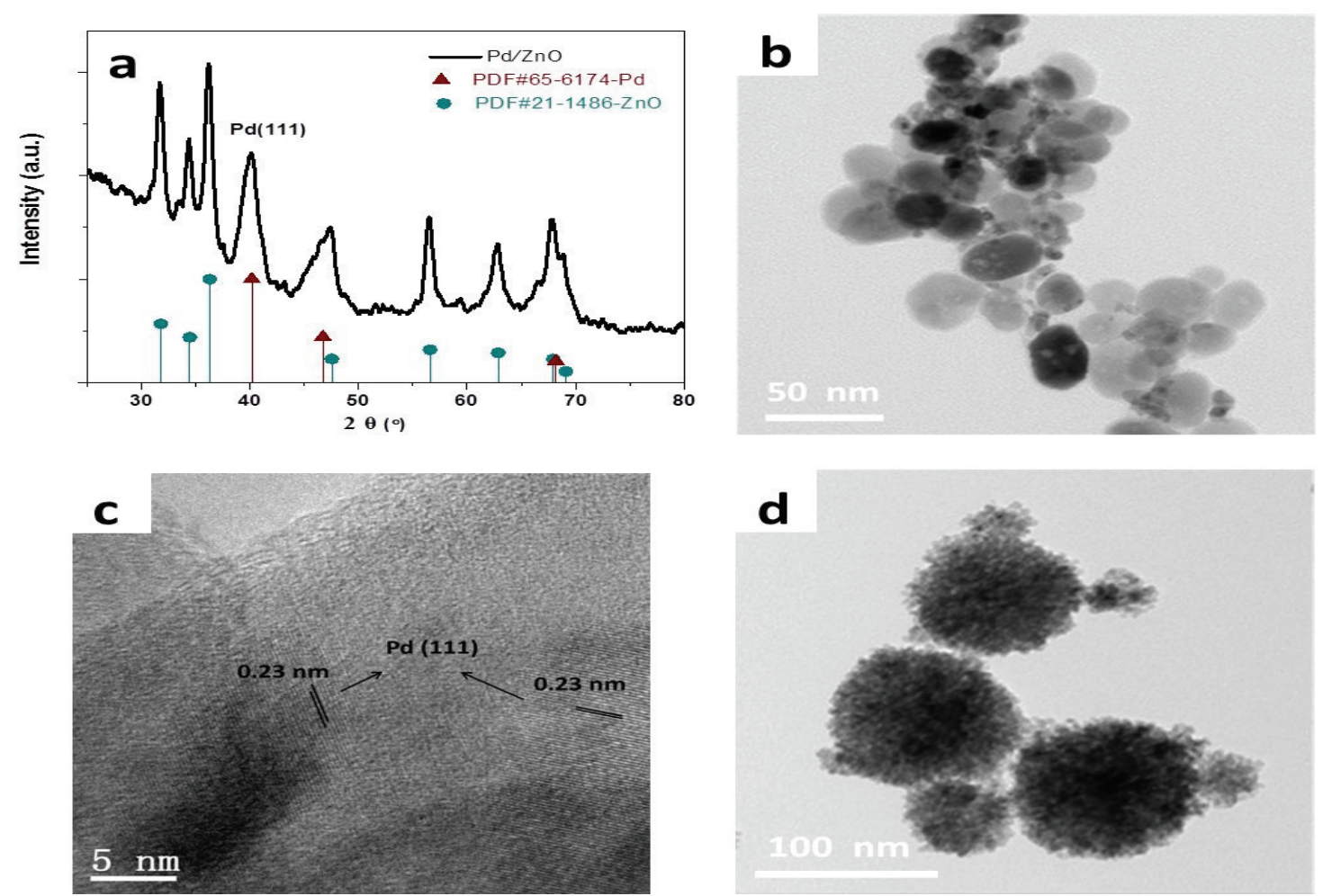

Fig. 2 (a) XRD pattern, (b) TEM and (c) high resolution TEM images of the Pd/ZnO sample prepared at a Pd/Zn ratio of $1: 6$, and (d) TEM image of pure $\mathrm{ZnO}$ sample.

Zn, Pd, O and C. More specifically, Fig. $3 b$ shows the highresolution spectra of $\mathrm{Zn} 2 p$. The binding energy at 1021.5 and $1044.6 \mathrm{eV}$ can be assigned to $\mathrm{Zn}$ (II) $2 p_{3 / 2}$ and $2 p_{1 / 2}$ in the form of $\mathrm{ZnO}$, respectively. The deconvolution of $\mathrm{O} 1 \mathrm{~s}$ using curve fitting in Fig. 2c clearly shows two main peaks, one being lattice
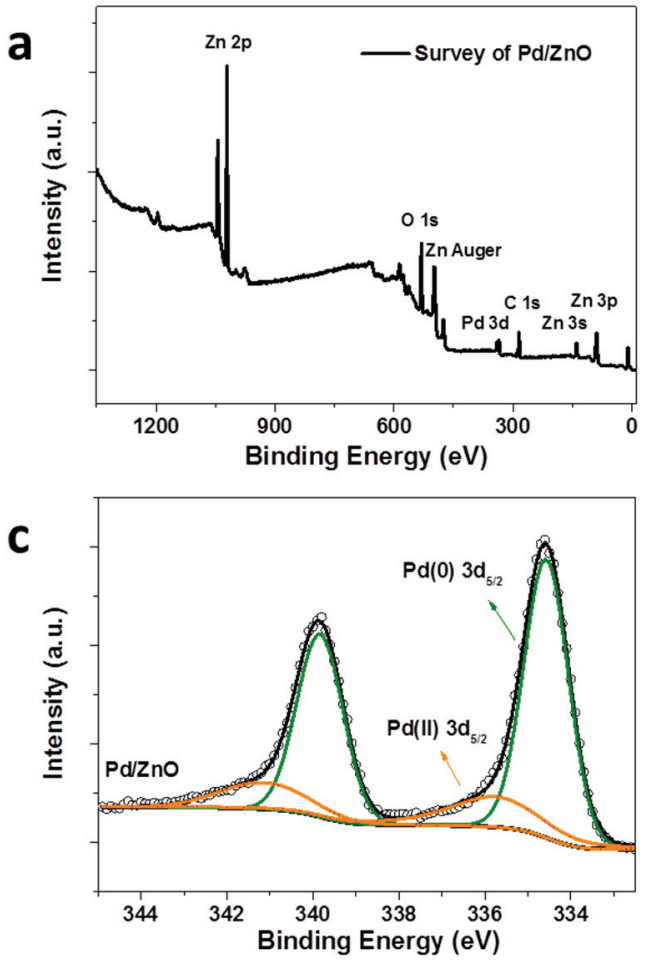

oxygen $\left(\mathrm{O}^{2-}\right)$ from $\mathrm{ZnO}$, the other being adsorbed oxygen on the surface of the composite ${ }^{28}$. The Pd $3 d$ spectrum (Fig. 3d) consists of two main peaks at binding energies of 339.9 and $334.6 \mathrm{eV}$, corresponding to $\mathrm{Pd} 3 d_{3 / 2}$ and $3 d_{5 / 2}$ of metallic $\mathrm{Pd}$ species ${ }^{29}$. Interestingly, the $\mathrm{Pd} 3 d$ region can be divided into two
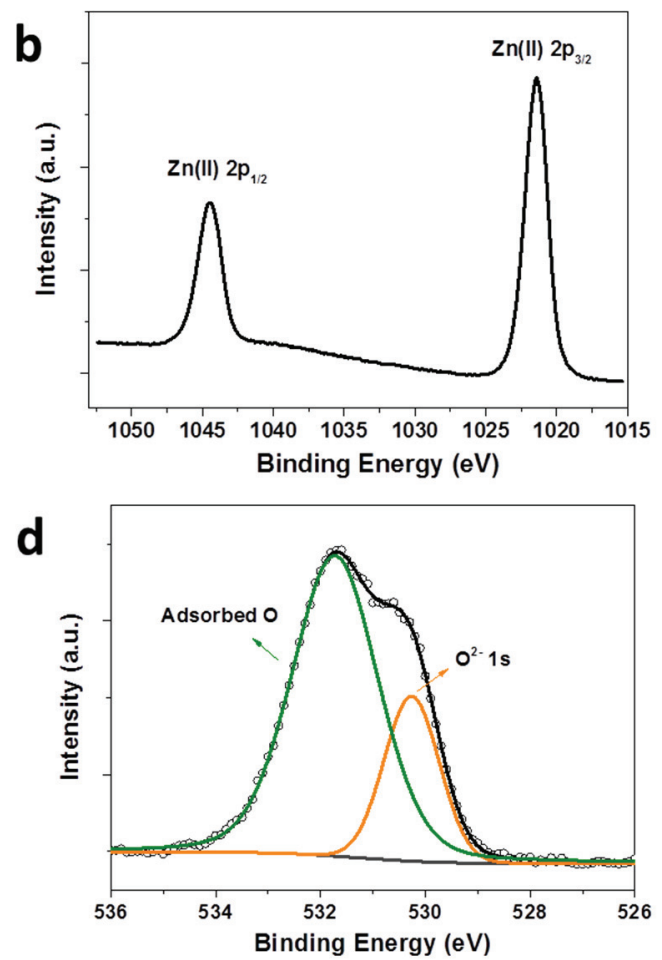

Fig. 3 XPS analysis of the Pd/ZnO nanocomposite. (a) The wide-range XPS spectrum; high resolution spectra of (b) Zn $2 p$, (c) Pd $3 d$, (d) O 1s. 

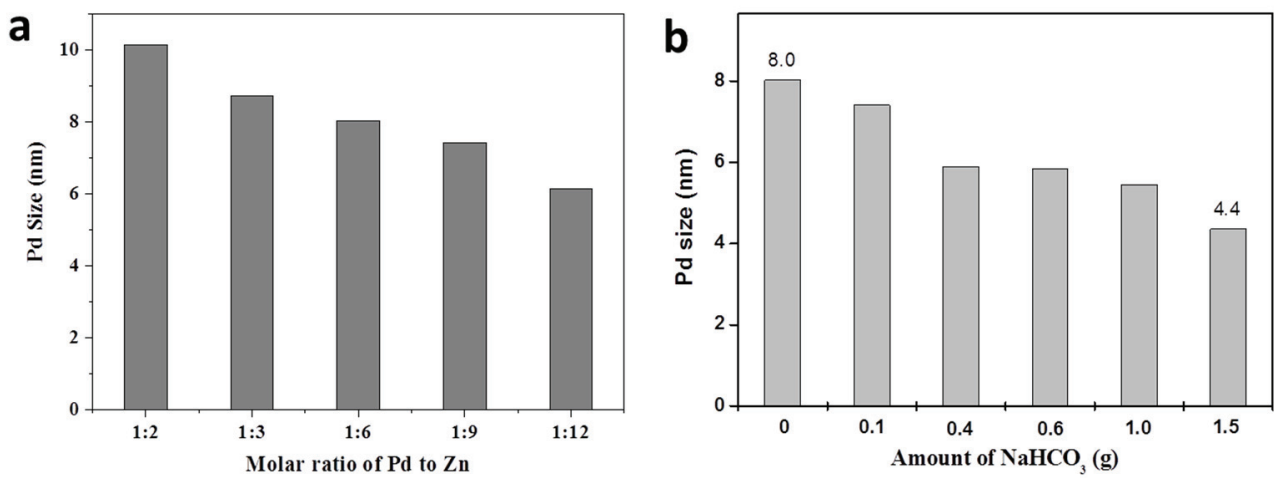

Fig. 4 Histogram of Pd particle size versus (a) the mole ratio of $\mathrm{Pd}$ to $\mathrm{Zn}$ and (b) the amount of $\mathrm{NaHCO}_{3}$.

peak groups, and the signals of higher binding energies $(341.2$ and $335.8 \mathrm{eV}$ ) come from partially oxidized $\mathrm{Pd}(\delta+)$, which accounts for around $21 \%$ of total surface Pd content. Many studies on oxide-supported metal clusters show that surface defects of the supports could serve as anchoring sites for metal clusters ${ }^{30}$. When $\mathrm{Pd}$ are immobilized onto the surface of $\mathrm{ZnO}$, Pd-O-Zn interfaces would form. This part of Pd normally shows positive charge via electron transfer from $\mathrm{Pd}$ to $\mathrm{ZnO}$, indicating strong interactions between $\mathrm{Pd}$ and $\mathrm{ZnO}$ (SMSI) ${ }^{31}$.

A series of $\mathrm{Pd} / \mathrm{Zn}$ molar ratios were investigated using this simple synthesis method. The final products were analyzed using ICP-MS to check the actual elemental compositions, as listed in Table S1 (in Supporting Information). The detected atomic ratios of $\mathrm{Pd} / \mathrm{Zn}$ are well consistent with the theoretical recipe value, evidencing a total conversion of initial $\mathrm{Pd}$ and $\mathrm{Zn}$ species to their corresponding products. It is quite advantageous to achieve a precise control of multi-component ratios by using this simple method. Fig. S1 shows XRD patterns of a series of $\mathrm{Pd} / \mathrm{ZnO}$ composites with the $\mathrm{Pd} / \mathrm{Zn}$ ratio varying from $1: 2$ to $1: 48$. As expected, when the ratio is reduced, the peak intensity ratio of $\mathrm{Pd}$ (111)/ZnO (002) decreases continually. At the same time, the widening of Pd (111) reveals a decreasing trend of the Pd size. According to the Scherrer formula, the particle size calculated on a basis of the Pd (111) peak goes up from $6.14 \mathrm{~nm}$ at $\mathrm{Pd} / \mathrm{Zn}$ molar ratio $=1: 12$ to $10.12 \mathrm{~nm}$ at $\mathrm{Pd} / \mathrm{Zn}$ molar ratio $=1: 2$. Fig. $\mathrm{S} 2$ shows TEM images of the $\mathrm{Pd} / \mathrm{ZnO}$ samples. Despite different Pd loading, all composites show similar morphology, with small $\mathrm{Pd}$ dots on sphere-like $\mathrm{ZnO}$ crystals. All $\mathrm{ZnO}$ particles have similar size of around $30 \mathrm{~nm}$, while the size of $\mathrm{Pd}$ particles varies with the $\mathrm{Pd} / \mathrm{Zn}$ molar ratios, as shown in Fig. 4a. When the Pd loading goes up, the corresponding $\mathrm{Pd}$ particle size also increases, in good agreement with aforementioned XRD analysis. This phenomenon may be attributed to relatively insufficient surface defects of $\mathrm{ZnO}$ to anchor extra Pd species, thus losing control of the growth of Pd particles.

The amount of $\mathrm{NaHCO}_{3}$ is another key factor to control the size of Pd NPs. By keeping the molar ratio of Pd/Zn at $1: 6$, we investigated the effect of the added amount of $\mathrm{NaHCO}_{3}$ on $\mathrm{Pd}$ size. Fig. S3 shows the XRD patterns of fresh samples with the dosage of $\mathrm{NaHCO}_{3}$ varying from $0,0.1,0.4,0.6,1.0$ to $1.5 \mathrm{~g}$.
Accordingly, the $\mathrm{Pd}(111)$ peak (at $40.24^{\circ}$ ) became widened and weakened, revealing a decrease of Pd size. The average sizes are calculated and shown in Fig. 4b. Clearly, it decreases gradually from 8.0 to $4.4 \mathrm{~nm}$ with increased amount of $\mathrm{NaHCO}_{3}$. This can be further confirmed by TEM observation, as seen in Fig. S4. It has been accepted that alkaline conditions would accelerate the initial nucleation of noble metals, thus favoring a smaller particle size ${ }^{32}$. Therefore, $\mathrm{NaHCO}_{3}$ can serve as a size-control tool for Pd NPs.

We also synthesized other $\mathrm{M} / \mathrm{ZnO}$ nanocomposites including $\mathrm{Au} / \mathrm{ZnO}, \mathrm{Ag} / \mathrm{ZnO}$ and $\mathrm{Cu} / \mathrm{ZnO}$ following the same strategy. XRD patterns (Fig. 5) confirm the formation of corresponding metal NPs supported on $\mathrm{ZnO}$. Precisely, all metals show their typical (111) diffraction peaks at a scanning region from $38^{\circ}$ to $45^{\circ}$. The intensity and width of diffraction peaks vary for different samples, indicative of apparent size difference. Among the three $\mathrm{M} / \mathrm{ZnO}$ systems, Au NPs show the largest size with around $30 \mathrm{~nm}, \mathrm{Ag}$ the second with around $15 \mathrm{~nm}, \mathrm{Cu}$ the smallest with only $9 \mathrm{~nm}$, as calculated from Scherrer formula. The size difference may be explained by different reduction potentials for selected metal precursors, thus affecting the subsequent growth process. Fig. S5 shows TEM images of the three samples and pure $\mathrm{ZnO}$. Clearly, we can see the incorporation of $\mathrm{Au}, \mathrm{Ag}$ and $\mathrm{Cu}$ species can also stabilize $\mathrm{ZnO}$ NPs from aggregation, similar to the aforementioned $\mathrm{Pd} / \mathrm{ZnO}$ system.

$\mathrm{Cu} / \mathrm{ZnO} / \mathrm{Al}_{2} \mathrm{O}_{3}$ composite is a well-known catalyst towards the catalytic hydrogenation of $\mathrm{CO}_{2}$ to produce methanol ${ }^{33}$. Other

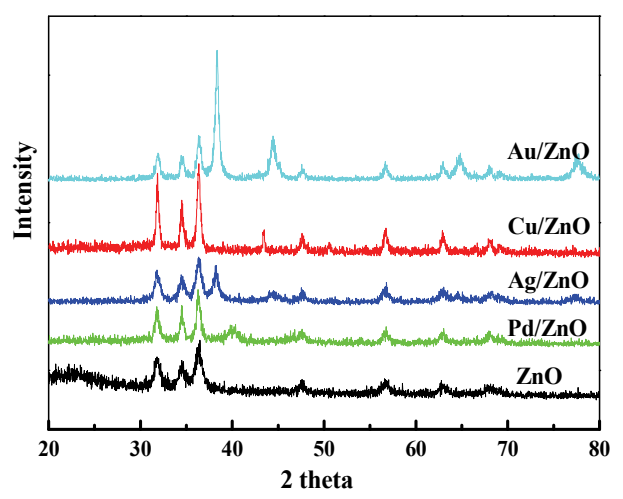

Fig. 5 XRD patterns of $\mathrm{ZnO}$ and $\mathrm{M} / \mathrm{ZnO}(\mathrm{M}=\mathrm{Pd}$, $\mathrm{Au}$, Ag, and Cu) synthesized at a $M / Z n$ molar ratio of 1 : 6 . 
Table 1 Catalytic performance of $\mathrm{M} / \mathrm{ZnO} / \mathrm{Al}_{2} \mathrm{O}_{3}$ catalysts $(\mathrm{M}=\mathrm{Ag}, \mathrm{Cu}, \mathrm{Au}$, and $\mathrm{Pd})$.

\begin{tabular}{|c|c|c|c|c|c|c|}
\hline Catalyst & $T /{ }^{\circ} \mathrm{C}$ & $\mathrm{CO}_{2}$ Conv. $(\%)$ & Methanol Select. (\%) & CO Select. $(\%)$ & Methanol Yield (\%) & Methanol STY $\mathrm{g}_{\text {methanol }} /\left(\mathrm{kg}_{\text {catalyst }} \cdot \mathrm{h}\right)$ \\
\hline $\mathrm{Ag} / \mathrm{ZnO}(1: 6)^{\mathrm{a}}$ & 260 & 21.9 & 26 & 74 & 5.7 & 114.5 \\
\hline $\mathrm{Cu} / \mathrm{ZnO}(1: 6)$ & 260 & 14.0 & 23 & 77 & 3.2 & 64.3 \\
\hline $\mathrm{Au} / \mathrm{ZnO}(1: 6)$ & 260 & 6.6 & 82 & 18 & 5.4 & 108.5 \\
\hline $\mathrm{Pd} / \mathrm{ZnO}(1: 6)$ & 260 & 20.7 & 71 & 29 & 14.7 & 295.3 \\
\hline $\mathrm{Pd} / \mathrm{ZnO}(1: 6)$ & 240 & 19.0 & 77 & 23 & 14.6 & 293.3 \\
\hline $\mathrm{Pd} / \mathrm{ZnO}(1: 6)$ & 220 & 9.8 & 84 & 16 & 8.2 & 164.7 \\
\hline $\mathrm{Pd} / \mathrm{ZnO}(1: 9)$ & 240 & 30.5 & 69 & 31 & 21.0 & 421.9 \\
\hline $\mathrm{Pd} / \mathrm{ZnO}(1: 12)$ & 240 & 21.6 & 83 & 17 & 17.9 & 359.6 \\
\hline $\mathrm{Pd} / \mathrm{ZnO}(1: 24)$ & 240 & 19.2 & 59 & 41 & 11.3 & 227.0 \\
\hline
\end{tabular}

${ }^{\mathrm{a}}$ The value refers to the recipe $\mathrm{M} / \mathrm{Zn}$ ratio. Reaction conditions: $5 \mathrm{MPa}$ of pressure, $\mathrm{CO}_{2} / \mathrm{H}_{2}=1: 3$, gas flow $=15 \mathrm{~mL} \cdot \mathrm{min}^{-1}$, catalyst loading $=0.24 \mathrm{~g}$.

metal/ZnO composites are also catalytically active for this reaction, such as $\mathrm{Pd} / \mathrm{ZnO}{ }^{34}$. We tested our one-pot synthesized $\mathrm{M} / \mathrm{ZnO}$ nanomaterials mixed with $\mathrm{Al}_{2} \mathrm{O}_{3} \quad(33.3 \%(w))$ as catalysts for the hydrogenation of $\mathrm{CO}_{2}$ (see Table 1). For the $\mathrm{Cu} / \mathrm{ZnO}$ and $\mathrm{Ag} / \mathrm{ZnO}$ catalyst, the methanol selectivity is very low, with a value of $23 \%$ and $26 \%$ respectively. The $\mathrm{Au} / \mathrm{ZnO}$ catalyst favors the highest methanol selectivity (82\%), but lowest $\mathrm{CO}_{2}$ conversion, with only $6.6 \%$. When the $\mathrm{Pd} / \mathrm{ZnO}$ is used, the $\mathrm{CO}_{2}$ conversion reaches $20.7 \%$ while the methanol selectivity is still kept at a high value (71\%), giving the highest methanol yield (14.7\%). The excellent catalytic performance may be explained by the following two factors: one is that $\mathrm{Pd}$ is a good catalyst for the dissociation of $\mathrm{H}_{2}$ to give active $\mathrm{H}$ atoms ${ }^{35}$, the other being that SMSI between $\mathrm{Pd}$ and $\mathrm{ZnO}$ would favour the formation of surface oxygen vacancies on $\mathrm{ZnO}^{36}$.

Reaction temperatures were then investigated over the $\mathrm{Pd} / \mathrm{ZnO}(1: 6)$ system. When the temperature is reduced from 260 to $240{ }^{\circ} \mathrm{C}$, the $\mathrm{CO}_{2}$ conversion slightly decreases from $20.7 \%$ to $19.0 \%$ while the methanol selectivity goes up marginally from $71 \%$ to $77 \%$, maintaining a nearly identical methanol yield (14.6\%). When the temperature further drops to $220{ }^{\circ} \mathrm{C}$, the $\mathrm{CO}_{2}$ conversion decreases to only $9.8 \%$ although a higher methanol selectivity (84\%) is achieved. The final methanol yield drops significantly from $14.6 \%$ to $8.2 \%$. A lower temperature would be favourable for the selectivity of methanol because this route is exothermic whilst the $\mathrm{CO}_{2}$-to- $\mathrm{CO}$ route is endothermic ${ }^{33}$. However, the total $\mathrm{CO}_{2}$ conversion rate would drop quickly with the decrease of temperature. Therefore, it is of great significance to choose a proper temperature for a desirable methanol yield.

The loading of $\mathrm{Pd}$ in $\mathrm{Pd} / \mathrm{ZnO}$ catalysts was further studied at a reaction temperature of $240{ }^{\circ} \mathrm{C}$, as summarized in Table 1 . When Pd loading is increased, the methanol yield increases first and then decreases, with a maximum of $21.0 \%$ at a $\mathrm{Pd} / \mathrm{Zn}$ ratio of $1: 9$. Similarly, the $\mathrm{CO}_{2}$ conversion also reached a peak (30.49\%) for this sample, along with an acceptable methanol selectivity (68.7\%). In general, the activity of $\mathrm{Pd} / \mathrm{ZnO}$ is closely related to the exposed Pd surface sites which determine the amount of dissociated $\mathrm{H}$ species. In our case, the Pd particle size shows an increased trend with increased loading content, which would in turn decrease the effective Pd surface sites. Therefore, the activity of $\mathrm{Pd} / \mathrm{ZnO}$ catalysts from our synthesis method would be very sensitive to the loading content of Pd.

\section{Conclusions}

In summary, we demonstrate a facile one-pot surfactant-free synthesis of $\mathrm{M} / \mathrm{ZnO}(\mathrm{M}=\mathrm{Pd}, \mathrm{Au}, \mathrm{Ag}$, and $\mathrm{Cu})$ nanocomposites in ethylene glycol under the refluxing condition. In this strategy, $\mathrm{Pd}$ and $\mathrm{ZnO}$ can stabilize each other from further aggregation. $\mathrm{Pd}$ loading can be precisely tailored by changing recipe $\mathrm{Pd} / \mathrm{Zn}$ ratios. $\mathrm{NaHCO}_{3}$ can serve as a size-control tool for Pd particles by adjusting alkaline conditions. It is also found that the $\mathrm{Pd} / \mathrm{ZnO}$ sample prepared by this simple method shows strong interactions between $\mathrm{Pd}$ and $\mathrm{ZnO}$, which promotes a high methanol yield at a $\mathrm{Pd} / \mathrm{Zn}$ ratio of $1: 9$. This facile method would open up a new route for one-pot synthesis of $\mathrm{M} / \mathrm{ZnO}$ nanocomposites with clean surface for catalysis.

Supporting Information: available free of charge via the internet at http://www.whxb.pku.edu.cn.

\section{References}

(1) Lewis, S. A.; Wilburn, J. P.; Wellons, M. S.; Cliffel, D. E.; Lukehart, C. M. Phys. Status Solidi A 2015, 212, 2903. doi: $10.1002 /$ pssa.201532256

(2) Chen, Y.; Yang, X. Y.; Zhang, P.; Liu, D. S.; Gui, J. Z.; Peng, H. L.; Liu, D. Acta Phys. -Chim. Sin. 2017, 33, 2082. [陈阳, 杨晓燕, 张 鹏, 刘道胜, 桂建舟, 彭海龙, 刘丹. 物理化学学报, 2017, 33, 2082.] doi: 10.3866/PKU.WHXB201705176

(3) Xu, B. Q.; Wei, J. M.; Yu, Y. T.; Li, Y.; Li, J. L.; Zhu, Q. M. J. Phys. Chem. B 2003, 107, 5203. doi: 10.1023/A:1021419929938

(4) Wang, Y. Acta Phys. -Chim. Sin. 2017, 33, 857. [王野. 物理化学学 报, 2017, 33, 857.] doi: 10.3866/PKU.WHXB201703172

(5) Rathi, A. K.; Gawande, M. B.; Ranc, V.; Pechousek, J.; Petr, M.; Cepe, K.; Varmab, R. S.; Zboril, R. Catal. Sci. Technol. 2016, 6, 152. doi: 10.1039/C5CY00956A

(6) Nadagouda, M. N.; Varma, R. S. Biomacromolecules 2007, 8, 2762. doi: $10.1021 / \mathrm{bm} 700446 \mathrm{p}$ 
(7) Zhang, J.; Yu, J. G.; Jaroniec, M.; Gong, J. R. Nano Lett. 2012, 12, 4584. doi: $10.1021 / \mathrm{nl} 301831 \mathrm{~h}$

(8) Liu, T. X.; Li, B. X.; Hao, Y. G.; Han, F.; Zhang, L. L.; Hu, L. Y. Appl. Catal. B-Environ. 2015, 165, 378.

doi: 10.1016/j.apcatb.2014.10.041

(9) Wang, D. H.; Kou, R.; Choi, D.; Yang, Z. G.; Nie, Z. M.; Li, J.; Saraf, L. V.; Hu, D. H.; Zhang, J. G.; Graff, G. L.; et al. ACS Nano 2010, 4, 1587. doi: 10.1021/nn901819n

(10) Polarz, S.; Neues, F.; van den Berg, M. W. E.; Grunert, W.; Khodeir, L. J. Am. Chem. Soc. 2005, 127, 12028. doi: 10.1021/ja0516514

(11) Behrens, M.; Studt, F.; Kasatkin, I.; Kühl, S.; Hävecker, M.; AbildPedersen, F.; Zander, S.; Girgsdies, F.; Kurr, P.; Kniep, B.; et al. Science 2012, 336, 893. doi: 10.1126/science.1219831

(12) Ma, J.; Sun, N.; Zhang, X.; Zhao, N.; Xiao, F.; Wei, W.; Sun, Y. Catal. Today 2009, 148, 221. doi: 10.1016/j.cattod.2009.08.015

(13) Wang, G. Y.; Zhang, W. X.; Lian, H. L.; Jiang, D. Z.; Wu, T. H. Appl. Catal. A 2003, 239, 1. doi: 10.1016/S0926-860X(02)00098-4

(14) Da Costa-Serra, J. F.; Guil-López, R.; Chica, A. Int. J. Hydrogen Energy 2010, 35, 6709. doi: 10.1016/j.ijhydene.2010.04.013

(15) Huang, L.; Kramer, G. J.; Wieldraaijer, W.; Brands, D. S.; Poels, E. K.; Castricum, H. L.; Bakker, H. Catal. Lett. 1997, 48, 55. doi: 10.1023/A:1019014701674

(16) Murray, C. B.; Norris, D. J.; Bawendi, M. G. J. Am. Chem. Soc. 1993, 115, 8706. doi: 10.1021/ja00072a025

(17) Sun, S. H.; Murray, C. B.; Weller, D.; Folks, L.; Moser, A. Science 2000, 287, 1989. doi: 10.1126/science.287.5460.1989

(18) Chen, S. F.; Li, J. P.; Qian, K.; Xu, W. P.; Lu, Y.; Huang, W. X.; Yu, S. H. Nano Res. 2010, 3, 244. doi: 10.1007/s12274-010-1027-z

(19) Zhang, H. Y.; Xie, Y.; Sun, Z. Y.; Tao, R. T.; Huang, C. L.; Zhao, Y. F.; Liu, Z. M. Langmuir 2011, 27, 1152. doi: 10.1021/la1034728

(20) Xie, Y.; Ding, K. L.; Liu, Z. M.; Tao, R. T.; Sun, Z. Y.; Zhang, H. Y.; An, G. M. J. Am. Chem. Soc. 2009, 131, 6648. doi: $10.1021 / \mathrm{ja} 900447 \mathrm{~d}$

(21) Wang, Y.; Ren, J. W.; Deng, K.; Gui, L. L.; Tang, Y. Q. Chem. Mater. 2000, 12, 1622. doi: 10.1002/chin.200041202
(22) Fu, X. Y.; Wang, Y.; Wu, N. Z.; Gui, L. L.; Tang, Y. Q. J. Mater. Chem. 2003, 13, 1192. doi: 10.1039/B211747A

(23) Zhang, J. L.; Ji, H.; Wei, Y. G.; Wang, Y.; Wu, N. Z. J. Phys. Chem. C 2008, 112, 10688. doi: 10.1021/jp8003294

(24) Chen, X. M.; Wu, G. H.; Chen, J. M.; Chen, X.; Xie, Z. X.; Wang, X. R. J. Am. Chem. Soc. 2011, 133, 3693. doi: 10.1021/ja110313d

(25) Sun, Y. G.; Gates, B.; Mayers, B.; Xia, Y. N. Nano Lett. 2002, 2 , 165. doi: $10.1021 / \mathrm{n} 1010093 \mathrm{y}$

(26) Ranjbar, M., Taher, M.A.; Sam, A. J. Clust. Sci. 2014, 25, 1657. doi: 10.1007/s10876-014-0764-7

(27) Zhang, J.; Mo, Y.; Vukmirovic, M. B.; Klie, R.; Sasaki, K.; Adzic, R. R. J. Phys. Chem. B 2004, 108, 10955. doi: 10.1021/jp0379953

(28) Jing, L. Q.; Xu, Z. L.; Sun, X. J.; Shang, J.; Cai, W. M. Appl. Surf. Sci. 2001, 180, 308. doi: 10.1016/S0169-4332(01)00365-8

(29) Batista, J.; Pintar, A.; Mandrino, D.; Jenko, M.; Martin, V. Appl. Catal. A-Gen. 2001, 206, 113. doi: 10.1016/S0926-860X(00)00589-5

(30) Matthey, D.; Wang, J. G.; Wendt, S.; Matthiesen, J.; Schaub, R.; Laegsgaard, E.; Hammer, B.; Besenbacher, F. Science 2007, 315 , 1692. doi: 10.1126/science. 1135752

(31) Qiao, B. T.; Wang, A.Q.; Yang, X. F.; Allard, L. F.; Jiang, Z.; Cui, Y. T.; Liu, J. Y.; Li, J.; Zhang, T. Nat. Chem. 2011, 3, 634. doi: $10.1038 /$ nchem.1095

(32) Bock, C.; Paquet, C.; Couillard, M.; Botton, G. A.; MacDougall, B. R. J. Am. Chem. Soc. 2004, 126, 8028. doi: 10.1021/ja0495819

(33) Chinchen, G. C.; Denny, P. J.; Jennings, J. R.; Spencer, M. S.; Waugh, K. C. Appl. Catal. 1988, 36, 1. doi: 10.1016/S0166-9834(00)80103-7

(34) Liang, X. L.; Dong, X.; Lin, G. D.; Zhang, H. B. Appl. Catal. BEnviron. 2009, 88, 315. doi: 10.1016/j.apcatb.2008.11.018

(35) Prüsse, U.; Vorlop, K. D. J. Mol. Catal. A-Chem. 2001, 173, 313. doi: 10.1016/S1381-1169(01)00156-X

(36) Liao, F. L.; Huang, Y. Q.; Ge, J. W.; Zheng, W. R.; Tedsree, K.; Collier, P.; Hong, X. L.; Tsang, S. C. Angew. Chem. Int. Ed. 2011, 50, 2162. doi: 10.1002/anie.201007108 